INEZ WATA

Warsaw University of Life Sciences

Warsaw

WIOLETTA WRÓBLEWSKA

University of Life Sciences

Lublin

\title{
THE INFLUENCE OF SELECTED DEMOGRAPHIC AND ECONOMIC FACTORS ON WARSAW INHABITANTS' ATTITUDE TO FRUIT AND VEGETABLES CONSUMED IN THE FORM OF CONVENIENCE FOOD
}

\begin{abstract}
In view of the fact that fruit and vegetables market is an important segment of food sector, this article presents the results of research on preferences of Warsaw residents in terms of fruit and vegetable products from the group of convenience food, including the knowledge and popularity of this type of products, evaluation of views and attitudes to this form of nutrition, the reasons for purchase and the declared purchase frequency. The studied consumers had different perception of this food category and their interest in it was not excessive. Especially age and social status were the variables differentiating the factors for choosing this type of food. Other determinants of the choice were taste, freshness, aroma, colour and quality. The rise in popularity of convenience food products, including fruit and vegetables, will be largely dependent on the proper promotional activities. These measures should aim not only at informing consumers about new products, but emphasise forming positive opinions on this type of food in the first place, and adjusting the offer to the structure of the needs of different purchasing groups. Juices and drinks, concentrates and vegetable purees forming a component for preparing meals as well as frozen products, purchased at the time of limited supply of fresh goods, are likely to be the most frequently purchased products.
\end{abstract}

Keywords: consumption, convenience food, fruit and vegetable products.

Kody JEL: D12, Q13, L66. 


\section{Introduction}

Modern society lifestyle, including food consumption, is constantly evolving (Buckley, Cowan and McCathy, 2007). The food market development causes the creation of new segments, including the market of convenience food. The increased interest in food referred to as "convenient" has been observed for many years in the world, and for over two decades in Poland (Kociszewski, 2007; Adamczyk, 2010; Mojka, 2012). The concept of convenience food / ready-to-eat meal ${ }^{1}$, has been present in scientific and everyday language for many years, but its interpretation can still be challenging. The main reason is dynamically changing consumer behaviour, especially in the sphere of their market decisions, which generate short product life cycles and the need for introducing continuous modification and innovation. The definitions of convenience food present in the literature (Gawęcki, 2002; Janicki, 1993, 2006; Kołożyn-Krajewska and Sikora, 2004; Babicz-Zielińska et al., 2010) identify convenience food as a component of a meal or as a ready-to-eat meal in preserved condition which - thanks to instructions on the package - enables to quickly prepare it for consumption. The common element of these numerous definitions of convenience food is its simplicity and the ability to shorten the meal preparation time. The development of convenience food segment is affected by changes in numerous factors, inter alia macroeconomic - including the economy development, a wide range of products in the consumer market and technological factors, with innovations enabling to enhance food preservation methods. Changes in economic factors imply, in turn, socio-cultural changes, inter alia the style and model of life organisation, leisure activities, increasing womens professional activity, extending the growth in the number of small households, the elderly and wealth of societies (Adamczyk, 2010).

Public awareness has been changing, and people are now guided not only by ownership and access to food, but also by convenience - the time and quality factor - that is short preparation time, but also good quality of food and nutrition efficacy (Makała, 2013). On the one hand, these are the producers developing new products and searching for new technologies that would attract and satisfy consumers, who act as engines driving the growth of convenience food market. On the other, the consumer himself - looking for new experience or specific expectations to be met with regard to products (Dąbrowska and Babicz-Zielińska, 2011).

From convenience food manufactures' point of view, demographic and economic variables referring to respondents, provide information about the status and structure of the individual group's demand, which makes the way to form market segmentation and categorises consumers target groups. In turn, knowledge of customer preferences allows for accurate design of new products, thus for meeting consumers' needs and producers' market success. Research in the field of con-

\footnotetext{
${ }^{1}$ The terms of the ready-to-eat meal / convenience food are used interchangeably in the paper.
} 
sumer's preferences as regards convenience food, revealed that this type of food is used most often by young people in small households, well off and better educated, but also by single people and those with no culinary aptitude (Szymańska, 2012; Babicz-Zielińska, 2010; Byrne, 1998; Verlegh and Candell, 1999; Gutkowska and Ozimek, 2005; Harris and Shiptsova, 2007). Easiness in preparation, convenience and time-saving are important factors in the selection of products from the group of convenience food (Krełowska-Kułas, 2005; Kozłowska, Szczecińska and Roszkowski, 2006). The study by Kabacińska and Nazarewicz (2005) indicated that ready-to-eat dishes made of vegetables were most frequently purchased by young convenience food consumers. While the main determinants of choice of the convenience food product is taste, shelf-life, flavour and price (Malczyk, Misiarz, Złoteńska-Synowiec and Ratajczyk, 2013).

The literature research indicates that the question of consumer behaviour in reference to convenience food market, depicts the market of fruit and vegetables in an insufficient way. Therefore, in view of the fact that fruit and vegetable market is an important segment of food sector in Poland, and that it brings about approximately $50 \%$ of fruit and $30 \%$ of vegetable production (Strategia krajowa..., 2013), this article presents the results of research on consumer preferences among Warsaw residents in terms of fruit and vegetable products from the group of convenience food, including the knowledge and popularity of this type of products, evaluation of views on and attitudes to this form of nutrition, the reasons for purchase and the declared purchase frequency.

\section{Research aim, sources and methods}

The aim of the article was to analyse the preferences of Warsaw inhabitants on fruit and vegetables purchased in the form of convenience food, depending on the impact of selected demographic and economic factors, i.e. sex, age, social status, education, household size and disposable income. Data for the analysis came from empirical studies conducted in Warsaw in the first half of 2016 with an exclusive questionnaire containing 10 closed-type questions. A survey among 200 respondents was conducted according to PAPI methodology when interviewing respondents in person. The number of surveyed respondents corresponds to the quantity typically applied in the research practice. According to Prymon (2001), when the extent of the research includes regional market, and the study field refers to consumer market, a survey should include 100-500 respondents. A sample group was selected as randomly-targeted, taking into account the fact that buying food products is strongly determined by sex. Women purchase food products relatively more often than men (CBOS, 2011). Thus, 67\% of the respondents were women and $33 \%$ men. Further demographic and economic characteristics of the respondents is presented in Table 1 . Due to the small number of respondents declaring their unemployed status and household size of more than 5 people, these two groups are not included in the analysis. 
In the questionnaire alternative and multialternative questions were included with a nominal scale application. The respondents task was to choose one or several answers by marking them, or making certain hierarchy within the specified rating measures. The questionnaire contained issues on, inter alia, knowledge of the concept of convenience food, the views and attitudes of consumers in relation to this type of food, the reasons for, the frequency and type of consumption and important factors when buying this type of product.

Table 1

Characteristics of the studied population

\begin{tabular}{|c|c|c|c|c|c|}
\hline Specification & $\begin{array}{c}\text { Total } \\
\text { number }\end{array}$ & $\begin{array}{c}\text { Structure } \\
\text { in } \%\end{array}$ & Specification & $\begin{array}{c}\text { Total } \\
\text { number }\end{array}$ & $\begin{array}{c}\text { Structure } \\
\text { in } \%\end{array}$ \\
\hline Total number & 200 & 100.0 & Social/professional status: & & \\
\hline $\begin{array}{l}\text { Sex: } \\
\text { - women } \\
\text { - men }\end{array}$ & $\begin{array}{c}134 \\
66\end{array}$ & $\begin{array}{l}67.0 \\
33.0\end{array}$ & $\begin{array}{l}\text { - unemployed } \\
\text { - pupil/student } \\
\text { - professionally active } \\
\text { - pensioner }\end{array}$ & $\begin{array}{c}15 \\
50 \\
107 \\
27\end{array}$ & $\begin{array}{l}7.5 \\
25.0 \\
53.5 \\
13.5\end{array}$ \\
\hline $\begin{array}{l}\quad \text { Age: } \\
-20-29 \\
-30-39 \\
-40-49 \\
-50-59 \\
->60\end{array}$ & $\begin{array}{l}49 \\
32 \\
42 \\
49 \\
26\end{array}$ & $\begin{array}{l}24.5 \\
16.0 \\
21.0 \\
24.5 \\
13.0\end{array}$ & $\begin{array}{l}\text { Net income per person } \\
\text { - up to PLN } 500 \\
\text { - PLN 501-1000 } \\
\text { - PLN 1001-2000 } \\
\text { - >PLN 2000 }\end{array}$ & $\begin{array}{l}47 \\
64 \\
58 \\
31\end{array}$ & $\begin{array}{l}23.5 \\
32.0 \\
29.0 \\
15.5\end{array}$ \\
\hline $\begin{array}{l}\text { Education level: } \\
\text { - primary school } \\
\text { - middle school } \\
\text { - university degree }\end{array}$ & $\begin{array}{l}25 \\
80 \\
95\end{array}$ & $\begin{array}{l}12.5 \\
40.0 \\
47.5\end{array}$ & $\begin{array}{l}\text { The number of people } \\
\text { in the household: } \\
-1-2 \text { people } \\
-3-4 \text { people } \\
-\geq 5 \text { people }\end{array}$ & $\begin{array}{c}43 \\
144 \\
14\end{array}$ & $\begin{array}{l}21.5 \\
72.0 \\
7.0\end{array}$ \\
\hline
\end{tabular}

${ }^{a}$ The income intended for consumer goods and services expenditure, including the growth in savings and when reduced by other expenses, i.e. donations, some taxes, such as inheritance and donation tax, property tax, fees for eternal use of the land, advance payment of income tax paid by the taxpayer.

Source: calculations and own study based on the research results.

The questionnaire used a 5-point Likert-type scale and positional scale, depending on the question. Respondents in the question concerning the reasons for the purchase, hierarchised the given options within a specified range between 1 and 7. In the analysis of these issues the descriptive statistics were applied, the sum of ratings for individual issues and their structure as well as the average value of the sum of ratings $(\overline{\mathrm{X}})$ and standard deviation $(\mathrm{SD})$ were estimated. In the questions about the relevance of the purchase factors and characteristics of vegetable and fruit products from the convenience food group, the resulting average numerical values were assigned to their rank, thus creating ranks of the choice determinants of food for the studied groups of respondents. In the case of observations of equal rank value variable, remarks were assigned the same rank, equal to an average of their sequence numbers, i.e. an incomplete value. 
Then, using the Spearman rank correlation coefficient, an analysis was carried out on the interdependence of ranks of the choice determinants of the convenience food between different groups of customers. To interpret the results, the following levels of correlation were presumed: $<0.2$ - no linear relationship; 0.2-0.4 - weak relationship; 0.4-0.7 - moderate dependence; 0.7-0.9 - a fairly strong relationship; $>0.9-$ a very strong relationship. A level of statistical significance was accepted at $\mathrm{p}=0.05$.

The analyses carried out are a part of a broader research in other agglomerations in Poland. Conclusions drawn from the analysis can be used by food producers in the process of building their marketing strategies, because the preference tests make it possible both to know the consumer trends and to compare the studies conducted on them so far, and they provide information about the consumers' needs.

\section{Study results}

Analysis indicates that the largest group of respondents (40\%) is able to define the concept of convenience food, $33 \%$ cannot clearly determine what products fall into this food segment, and $27 \%$ had never met with this concept. However, nearly $70 \%$ of respondents, being given hints in the questions, correctly chose the definition of convenience food, while $42 \%$ said that it is a functional food, and $61 \%$ recognised it as widely available. Among consumers there is, therefore, no clearly understood definition of this group of food products. According to Olejniczak and Sojkin (2008), perception of convenience food is strongly associated with age and household size. This is also confirmed in this study since the high level of knowledge of terminology was mostly demonstrated by students, young people aged 20-29 and 30-39, as well as in the households of 1-2 people. In the analysed groups pensioners and people over 60 are characterised by the weakest recognition of the term convenience food. However, while officially scientists-adopted identification of food, in the consumers' group it is often interpreted ambiguously. Most consumers intuitively associate this type of food with the convenience and ease of use in preparing food. Therefore, the level of unawareness of the definition of convenience food does not correlate with the practice of purchasing power of consumers, i.e. most of them buy fruit and vegetable products from the group of convenience food with no knowledge of its classification.

The analysis of empirical material shows that Warsaw residents purchase fruit and vegetable products from the group of convenience food several times a month on average. Similar results referring to the frequency of convenience food consumption are also presented by Babicz-Zielińska et al. (2010). In the group of convenience vegetable products, concentrates and purees are favourites, and the frequency of their purchase amounted to an average of 3.51. They are relatively more often bought comparing to other vegetable products, i.e. several 
times a week (Fig. 1). With such frequency they were purchased by nearly every third respondent. In the case of fruit, similar purchase frequency was observed in the three groups of convenience products, i.e. juices, jams and desserts. These are purchased several times a week by respectively $30.5 \%, 23.0 \%$ and $18.5 \%$, of respondents. Vegetable juices occurred to be the least popular in convenience food group $(\overline{\mathrm{X}}=2.31, \mathrm{SD}=1.14)$, whereas fruit snacks are the least common in the fruit products $(\overline{\mathrm{X}}=1.94, \mathrm{SD}=0.99)$.

The analysed demographic and economic factors with a non-uniform intensity slightly differentiated consumer preferences in terms of the structure and frequency of purchasing vegetable and fruit products from convenience food group. Taking into account respondents' gender, frequency of consumption of various product groups was similar, though women are slightly more likely than men to acquire lettuce mix as well as fruit and snacks, while men are more likely to purchase jams. The analyses by Krełowska-Kułas (2005) also showed that gender has no significant impact on the frequency of consumption of products belonging to convenience food group. In the studied population, there was no significant impact of income, the number of people in the household and the education level on the frequency of purchase of products of vegetable and fruit from convenience food group. On the other hand, age was a substantial factor in differentiating consumer preferences, particularly in the two extreme age ranges, i.e. 20-29 year-old and those over 60. Although the two groups usually purchased concentrates and purees $(\overline{\mathrm{X}}=3.20, \mathrm{SD}=1.00$ and $\overline{\mathrm{X}}=3.38, \mathrm{SD}=1.18)$, young people were buying stir-fry vegetables in the second place $(\overline{\mathrm{X}}=3.18, \mathrm{SD}=1.14)$, as well as juices and nectars $(\overline{\mathrm{X}}=3.84, \mathrm{SD}=1.08)$, while people over 60 - pickled vegetables $(\overline{\mathrm{X}}=3.27, \mathrm{SD}=119)$, frozen food $(\overline{\mathrm{X}}=2.81, \mathrm{SD}=1.04)$ and fruit desserts $(\overline{\mathrm{X}}=3.00, \mathrm{SD}=1.11)$. In contrast, the least frequently purchased by young people were fruit salads $(\overline{\mathrm{X}}=1.94, \mathrm{SD}=1.02)$, pickled vegetables $(\overline{\mathrm{X}}=2.14, \mathrm{SD}=1.05)$ and vegetable juices $(\overline{\mathrm{X}}=2.37, \mathrm{SD}=1.26)$, and for the elderly - stir-fry vegetables, frozen food, fruit and fruit snacks (respectively, $\overline{\mathrm{X}}=1.96, \mathrm{SD}=1.06 ; \overline{\mathrm{X}}=1.88, \mathrm{SD}=1.05 ; \overline{\mathrm{X}}=1.67, \mathrm{SD}=0.86$ ). In a similar manner as age, consumer behaviour was differentiated by social status, i.e. pupils and students acquired convenience products slightly more often than pensioners.

The above analysis shows that the market of convenience fruit and vegetable products is under development. Yet, convenient and quick consumption, determined by lifestyle changes, will be an increasing part of Poles' habits. According to the survey, nearly $50 \%$ of respondents rarely or never plan their meals, $37 \%$ of them do it sometimes, and only every third respondent - often and very often. Comparing to all respondents, men and young people, aged 20-29 are the least likely to plan their meals. Thus, it can be concluded that the majority of people in these groups are potential buyers of convenience fruit and vegetable products. 


\section{Vegetable products}

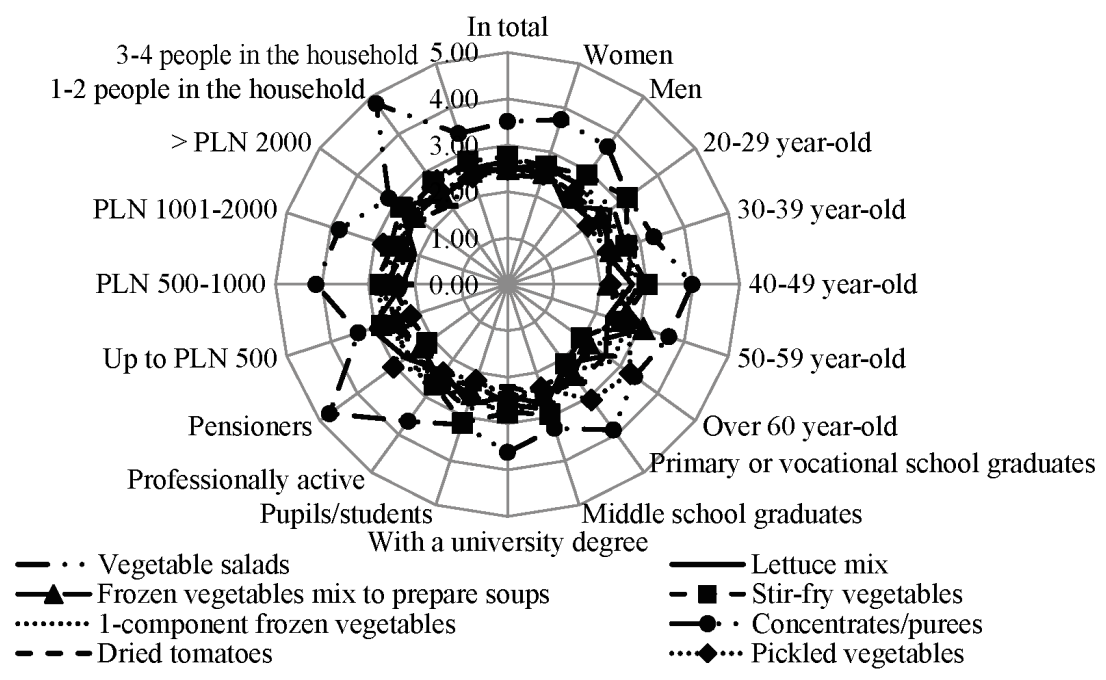

\section{Fruit products}

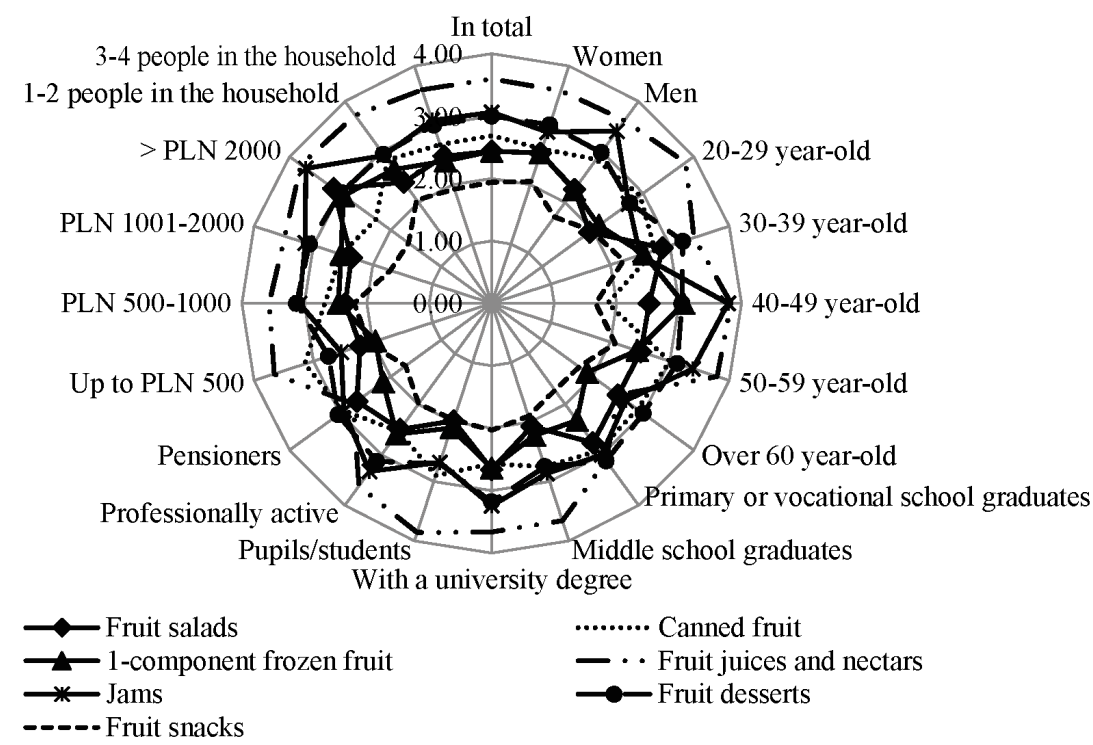

Fig. 1. The frequency of purchasing selected fruit and vegetable products from the group of convenience food by Warsaw inhabitants, considering the demographic and economic characteristics (average score on the 1-5 scale, where 1 - never, 2 - less frequently than once a month, 3 - a few times a month, 4 - a few times a week, 5 - every day or almost every day). Source: calculations and own study based on the research results. 
The most important reasons for purchasing fruit and vegetable products from the convenience food group declared by respondents were: the speed of preparation $(\overline{\mathrm{X}}=2.95, \mathrm{SD}=1.80)$, comfort $(\overline{\mathrm{X}}=3.27, \mathrm{SD}=1.99)$ and lack of time $(\overline{\mathrm{X}}=3.43, \mathrm{SD}=1.72)$ (Fig. 2). The study by Kowalczuk (2004), Krełowska-Kułas (2005) and Olejniczak (2010) also demonstrated that main factors of choosing convenience food were connected with practical aspects, i.e. ease of preparation, convenience and time savings. In the studied Warsaw population, one of the three most important reasons for the purchase was the time of meals preparation as declared by $64 \%$ of people. While $59 \%$ of the respondents indicate preparation convenience and $56.5 \%$ of them - lack of time. As the results of the conducted studies show, demographic and economic factors do not significantly differentiate the reasons for the purchase of fruit and vegetable convenience food. The convenience, speed of preparation and lack of time are the reasons for buying convenience food slightly more often by young people and students, though. Men relatively more frequently than women declared lacking in culinary abilities as the reason for buying convenience food. While for those who declared the highest level of disposable income, the most important were the flavour of the products. Buying this type of food was least determined by the novelties on the market and the lack of culinary talents.

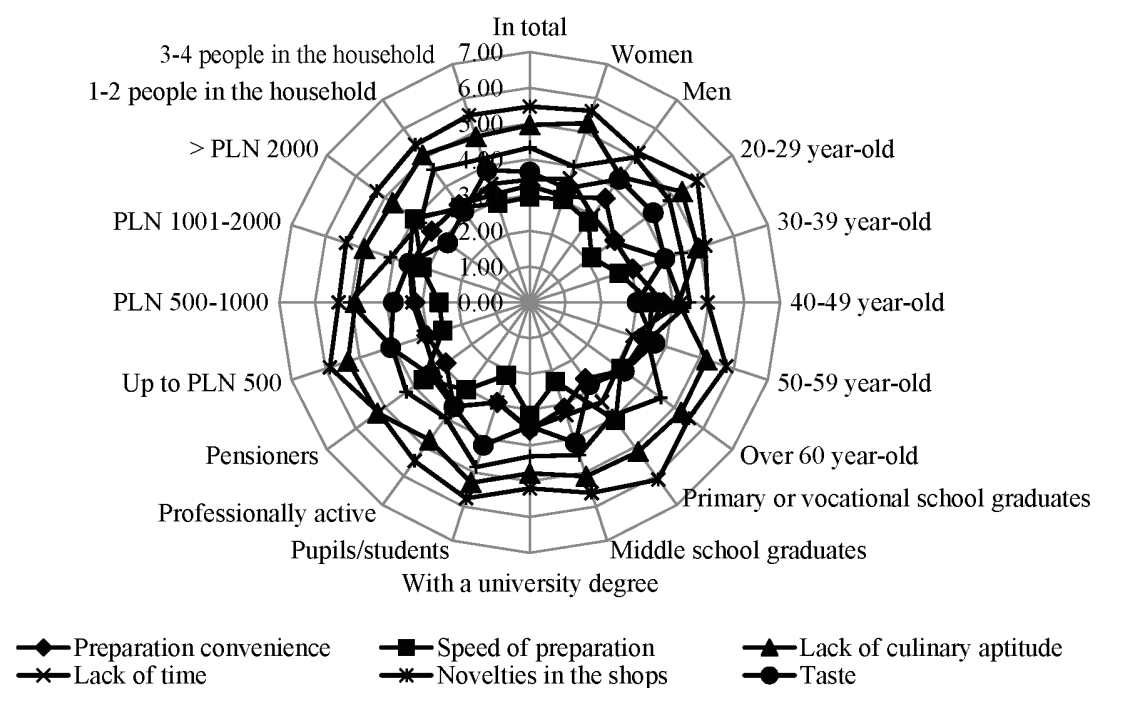

Fig. 2. Reasons for buying fruit and vegetable products from the convenience food group and an average degree of significance (average rating in the 1-7 ranking, where 1 - the most important reason, 7 - the least important reason).

Source: calculations and own study based on the research results. 
The surveyed consumers differently perceive the analysed food category. Only $14 \%$ and $8.5 \%$ of them believe that - respectively - "convenience food is wholesome" $(\overline{\mathrm{X}}=2.94, \mathrm{SD}=1.22)$ and ,convenience food is safe for health" $(\bar{X}=2.97, \mathrm{SD}=1.22)$. Men, more often than women, consider convenience food as wholesome and safe for health, as it is also assumed by young people, pupils and students, middle school graduates and those with lower levels of disposable income (Fig. 3). On average, every fourth respondent when purchasing fruit and vegetables from the convenience food group, pays attention to the product's country of origin. Consumer patriotic attitude increases along with age and higher income levels. Domestic fruit and vegetable products from the convenience food group were more frequently chosen by women. Increasing consumer awareness makes buyers more and more attentive as regards the quality of the product and the information contained on its label. For nearly $30 \%$ of the respondents the quality of the product determinant is its high price, especially for people with a stable financial situation, i.e. at the age of 40-49 and the level of disposable income of more than PLN 2000. Average ratings for this declaration was $3.04(\mathrm{SD}=1.37)$. While for $45 \%$ of the respondents the manufacturer's name is synonymous with the product's quality, and the demographic and economic factors did not significantly differentiate the surveyed group $(\bar{X}=2.91, \mathrm{SD}=1.35)$.

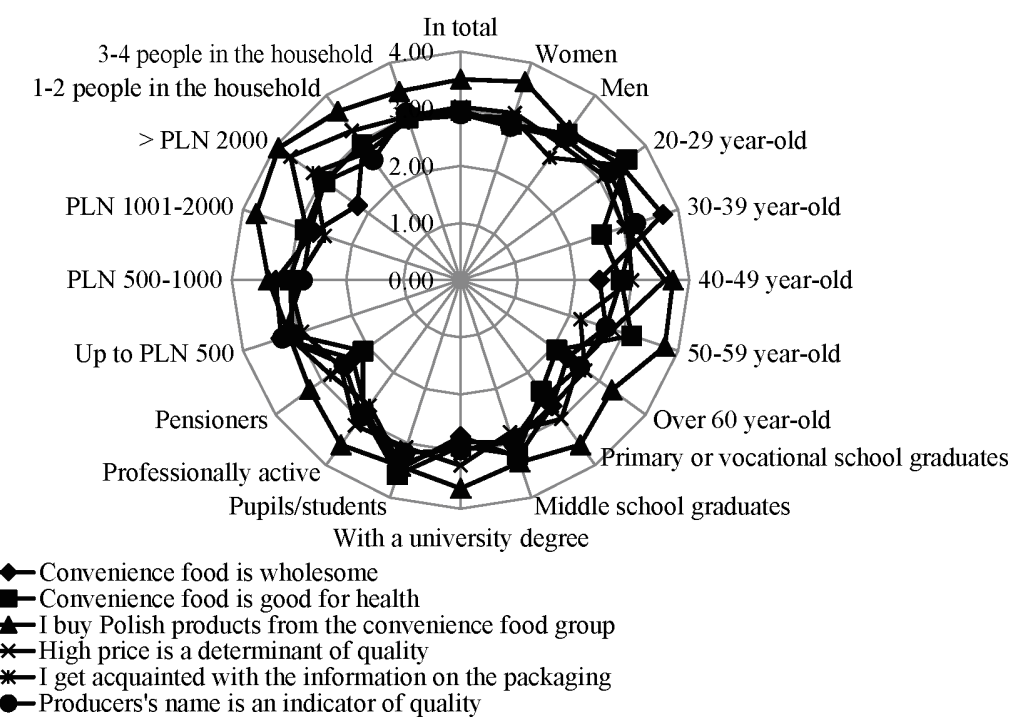

Fig. 3. Attitude of Warsaw citizens as regards fruit and vegetable products from the convenience food group (average score on the 1-5 scale, where 1 means - I do not agree with the statement, 5 - I agree with the statement).

Source: calculations and own study based on the research results. 
Approximately $45 \%$ of the respondents read the information on the product's packaging. When buying, the most important information on the label of the discussed group of products are: the expiration date $(\overline{\mathrm{X}}=4.25, \mathrm{SD}=1.00)$, ingredients $(\overline{\mathrm{X}}=4.02, \mathrm{SD}=1.01)$ and the producer's name $(\overline{\mathrm{X}}=3.94, \mathrm{SD}=0.95)$. In total, $82.5 \%, 71.0 \%$ and $70.0 \%$ of the respondents consider these as very important and important, respectively. The least important information on convenience product labelling, according to the respondents, regardless of the demographic and economic factors, are its calorific value and the quality label (Fig. 4).

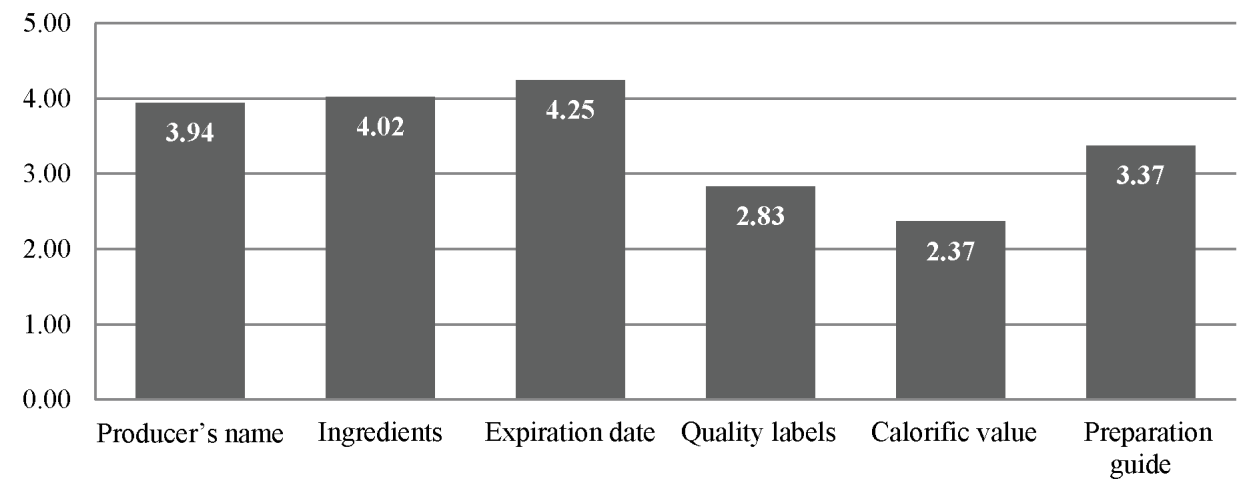

Fig. 4. Information on the packaging of fruit and vegetable products from the convenience food group and an average grading of significance in the opinion of the residents of Warsaw (average score on the 1-5 scale, where 1 means - void, 5 - very important).

Source: calculations and own study based on the research results.

The consumer decisions are influenced by numerous factors, which differently influence the process of making a choice. Each product is a set of features generating benefits for the buyer. In the case of products from the convenience food group, in addition to the basic values related to providing the organism with nutrients, we have to deal with other measurable characteristics that can determine the purchasing decisions of consumers. Using the method of assessing the relevance of choice factors on the 1 to 5 scale (where 5 is the most important factor), it was demonstrated that the main determinants of Warsaw consumers' purchasing decisions in the field of fruit and vegetable products from the group of convenience food, include sensory properties of the product, i.e. taste $(\bar{X}=4.80)$, freshness $(\bar{X}=4.77)$ and smell $(\bar{X}=4.50)$. The significance of these factors in the different groups of respondents is also demonstrated by low values of the standard deviation of their rank, which is $0.46,0.57$ and 0.55 . In total, $100 \%, 97.5 \%$ and $92 \%$ of the respondents indicated them as very important and important choice factors, respectively. The analysed demographic and economic factors did not essentially differentiate answers regarding sensory factors, only 
the hierarchy of importance slightly changed. In turn, the least important when buying convenience fruit and vegetable products by respondents from Warsaw, were calorific value $(\bar{X}=2.62)$, new products on the market $(\bar{X}=2.77)$, and, surprisingly - the nutrient content $(\overline{\mathrm{X}}=2.79)$. This low average rating of nutrient content as a factor of choice for the buyers, may result from the common belief that products processed in different ways have lower nutritional quality. Thus, this factor was assessed as of little importance in the hierarchy when purchasing these products. These three factors were positioned as last ones out of 22 analysed choice factors, i.e. on $22^{\text {nd }}, 21^{\text {st }}$ and $20^{\text {th }}$ place in the ranking (Table 2). The biggest discrepancies in the hierarchy of choice factors were related to the content or aroma, vitamins and availability on the market. In the case of these factors, the standard deviation for the assigned rank in all studied groups was respectively $4.23,3.61$ and 3.21 . Table 2 depicts the rank of the relevance of choice factors and characteristics of this food group products in respect to buyers from Warsaw, considering demographic and economic factors.

For convenience food producers the decisive factor as regards the success of the new product is, i.e. information concerning the rank of choice factors that guide individual groups of customers and the level of diversity of opinions between these groups. This information allows for accurate design of products for specific target groups of customers. Table 3 shows the correlation significance of factors of convenience food choice between different groups of customers. There was an analysis conducted in the first place, on the correlation between the opinions of the respondents in general and particular social groups regarding the importance of factors for choosing this type of food. As the results of the study show, there was a strong correlation in the opinions observed in the majority of cases. The largest discrepancies compared to the general opinions on the significance of choice factors referred to people in their 20s, over 60 as well as students and pensioners. However, even in these cases the opinions presented a strong correlation level in the range between $0.8-0.85$. Next, there was an analysis made on the interdependence between the opinions about the ranks of ready-to-eat products choice factors in different social groups. The results revealed that the features differentiating the opinions on the relevance of choice factors were age and social status. Between groups of people aged 20-29 and those over 60, students and people over 60 (the correlation coefficient 0.52 ) and those in their $20 \mathrm{~s}$ and retired (0.55), had the lowest values of the correlation coefficient, which indicated a moderate opinion bond. 


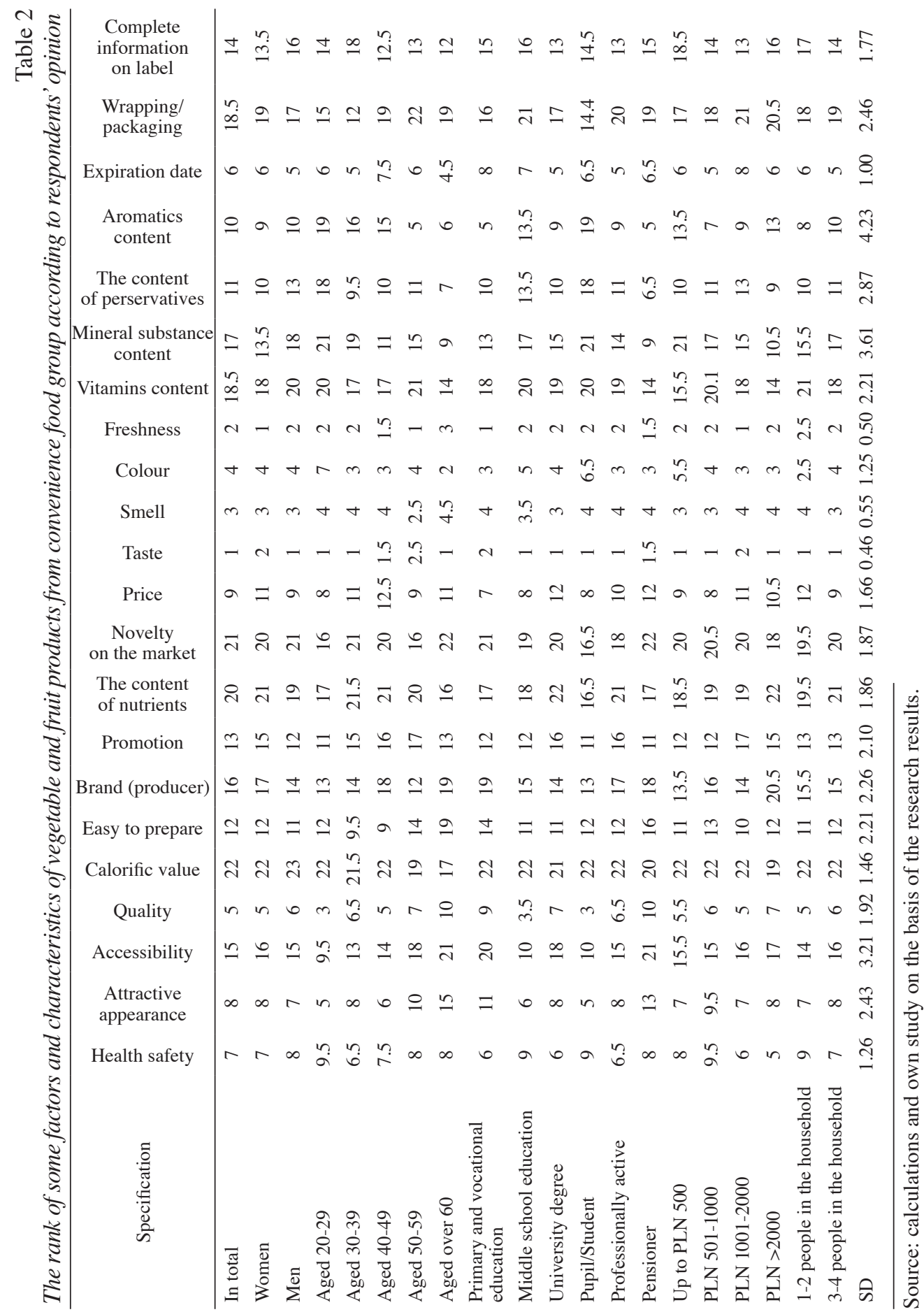




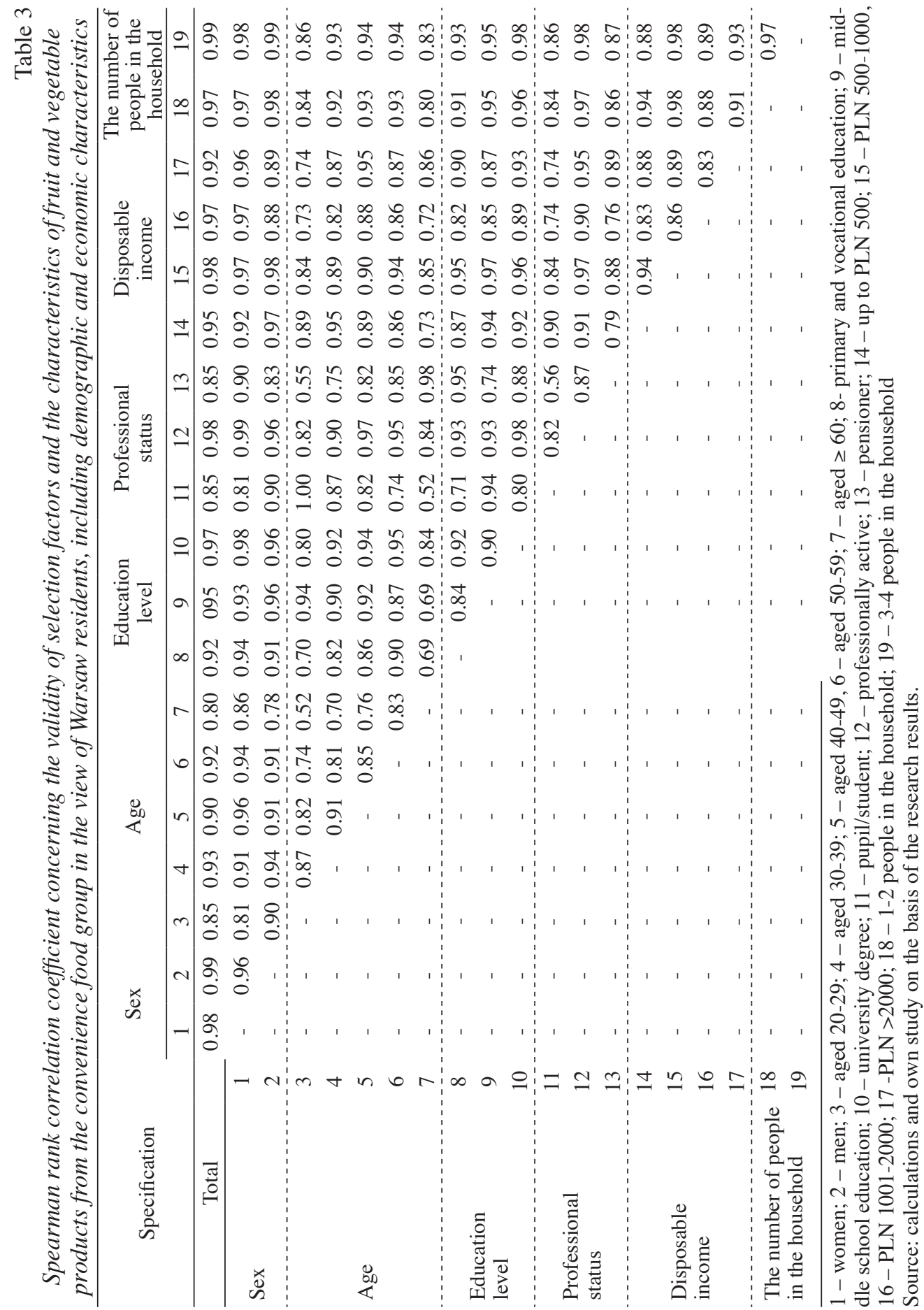




\section{Conclusions}

The results of this study show that consumers from Warsaw can be hardly recognised as enthusiasts of fruit and vegetable products from the group of convenience food. The studied consumers had different perception of this food category and their interest in it was not excessive. The analysed demographic and economic factors, especially age and social status linked to it, were the variables differentiating the factors for choosing this type of food. A relatively higher level of younger consumers interest is influenced by practical aspects, such as speed and ease of preparation, rather than by a desire to try them. Other determinants of the choice of the analysed products were taste, freshness, aroma, colour and quality. The calorific content, novelties on the market, the content of nutrients and vitamins, or lack of culinary talents, did not determine the interest in this type of food.

It may be assumed that the rise in popularity of convenience food products, including fruit and vegetables, will be largely dependent on the proper promotional activities. These measures should aim not only at informing consumers about new products, but emphasise forming positive opinions on this type of food in the first place, and adjusting the offer to the structure of the needs of different purchasing groups. On the one hand, we can expect that consumers behaviour, especially the young ones, will in the coming years be characterised by adapting European and world consumption patterns, i.e. an increase in the consumption of this type of food. On the other hand, the increasing role of consumption patterns of traditional and regional food (Sieczko and Wojcieszyńska, 2013; Rejman et al., 2015), including fresh fruit and vegetables, with their market supply steadily increasing, may provide a counterbalance to the market for fruit and vegetable from the convenience food group. It is difficult to predict the changes direction and dynamics of the intake of convenience fruit and vegetable. Juices and drinks, concentrates and vegetable purees forming a component for preparing meals as well as frozen products, purchased at the time of limited supply of fresh goods, are likely to be the most frequently purchased products. 


\section{References}

Adamczyk, G. (2010). Popularność żywności wygodnej. Journal of Agribusiness and Rural Developmend, no. 4(18), pp. 5-13.

Buckley, M., Cowan, C., McCarthy, M. (2007). The convenience food market in Great Britain: Convenience food lifestyle (CFL) segments. Appetite, no. 49, pp. 600-617.

Babicz-Zielińska, E. (2010). Postawy konsumentów wobec nowej żywności. Zeszyty Naukowe Akademii Morskiej w Gdyni, no. 65, pp. 16-22.

Babicz-Zielińska, E., Jeżewska-Zychowicz, M., Laskowski, W. (2010). Postawy i zachowania konsumentów w stosunku do żywności wygodnej. Żywność. Nauka. Technologia. Jakość, no. 4(71), pp. 141-153.

Babicz-Zielińska, E., Zabrocki, R. (2007). Konsument XXI wieku. Przemyst Spożywczy, no. 1, p. 7 .

Byrne, D. (1998). The state we're in. Marketing, no. 2, pp. 14-15.

CBOS (2011). Mania kupowania, czyli o postawach konsumenckich Polaków. Warsaw: Fundacja Centrum Badania Opinii Społecznej. Retrieved from: www.cbos.pl/SPISKOM. POL/2011/K_005_11.PDF (data dostępu: 15.05.2016).

Dąbrowska, A., Babicz-Zielińska, E. (2011). Zachowania konsumentów w stosunku do żywności nowej generacji. Hygeia Public Health, no. 46(1), pp. 39-46.

Gawęcki, J. (2002). Żywność nowej generacji a racjonalne żywienie. Żywność. Nauka. Technologia. Jakość, no. 4 (33), pp. 6-14.

Gutkowska, K., Ozimek, I. (2005). Wybrane aspekty zachowań konsumentów na rynku żywności - kryteria zróżnicowania. Warszawa: SGGW.

Harris, J.M.,Shiptsova,R.(2007). Consumer Demand for Convenience Foods: Demographics and Expenditures. Journal of Food Distribution Research, no. 38(3), pp. 22-36.

Janicki, A. (2003). Żywność wygodna; definicje i etapy rozwoju. Przemysł Spożywczy, no. 9, pp. 227-230.

Janicki, A. (2006). Żywność wygodna. W: F. Świderski (ed.), Żywność wygodna i żywność funkcjonalna, wyd. 3. Warszawa: WNT.

Kabacińska, A., Nazarewicz, R. (2005). Czynniki wyboru i częstotliwość spożycia żywności wygodnej. Roczniki Naukowe SERiA, vol. VII, issue 8, pp. 93-97.

Kociszewski, M. (2007). Rynek żywności wygodnej w Polsce. Przemyst Spożywczy, no. 10, pp. 24-29.

Kołożyn-Krajewska, D., Sikora, T. (2004). Towaroznawstwo żywności. Warszawa: WSiP.

Kowalczuk, I. (2004). Uwarunkowania konsumpcji koncentratów spożywczych. Acta Scientiarum Polonorum. Technologia Alimentaria, no. 3(1), pp. 187-198.

Kozłowska, K., Szczecińska, A., Roszkowski, W. (2006). Perception of convenience food by older people living in Warsaw. Polish Journal of Food Nutrition Sciences, no. 15/56, issue 2, pp. 227-233.

Krełowska-Kułas, M. (2005). Badanie preferencji konsumenckich żywności wygodnej. Zeszyty Naukowe Akademii Ekonomicznej w Krakowie, no. 678, pp. 141-148.

Makała, H. (2013). Trendy w produkcji żywności wygodnej i przykłady jej zastosowania w turystyce - wybrane aspekty. Zeszyty Naukowe Turystyka i Rekreacja, no. 12(2), Warszawa: Wyższa Szkoła Turystyki i Języków Obcych, pp. 105-118. 
Malczyk, E., Misiarz, M., Złoteńska-Synowiec, M., Ratajczyk, D. (2013). Zachowania nabywcze wybranej grupy studentów wobec mrożonej żywności wygodnej. Pielęgniarstwo i Zdrowie Publiczne, vol. 3, no. 3, pp. 249-255.

Mojka, K. (2012). Wybrane produkty żywności wygodnej - ocena preferencji i częstotliwości ich spożycia wśród studentów. Problemy Higieny i Epidemiologii, no. 93(4), p. 828-833 .

Olejniczak, T. (2010). Determinanty zachowań konsumentów na Polskim rynku żywności wygodnej. Zeszyty Naukowe Uniwersytetu Szczecińskiego. Problemy Zarzadzania, Finansów i Marketingu, no. 16, pp. 321-331.

Olejniczak, T., Sojkin, B. (2008). Postrzeganie nowoczesnej żywności przez polskich konsumentów. W: Z. Kędzior, G. Maciejewski (ed.), Zachowania konsumentów - stagnacja czy zmiana? (pp. 103-119). Katowice: Wydawnictwo Akademii Ekonomicznej w Katowicach.

Prymon, M. (2001). Współczesne badania marketingowe. Lublin: Redakcja Wydawnictw Katolickiego Uniwersytetu Lubelskiego.

Rejman, K., Halicka, E., Nagalska, H. (2015). Szanse polskiego rynku żywności tradycyjnej i regionalnej a zachowania konsumentów. Wieś i Rolnictwo, no. 3(168), pp. 117-132.

Sieczko, A., Wojcieszyńska, Z. (2013). Produkty tradycyjne i regionalne jako szansa rozwoju przedsiębiorczości wiejskiej. Folia Pomeranea Universitatis Technologiae Stetinensis, Oeconomica, no. 299(70), pp. 181-190.

Strategia krajowa dla zrównoważonych programów operacyjnych organizacji producentów owoców $i$ warzyw w Polsce na lata 2010-2016. Dziennik Urzędowy Ministra Rolnictwa i Rozwoju Wsi, poz. 39, Załącznik do informacji Ministra Rolnictwa i Rozwoju Wsi z dn. 8 listopada 2013 r., Warszawa 2013, pp. 2-3 (25.01.2016).

Szymańska, A. (2012). Jakość tzw. „żywności wygodnej”, na przykładzie wyników kontroli jakości handlowej koncentratów spożywczych. Wiedza i jakość, no. 3(26), pp. 7-10.

Verlegh, P.W.J., Candell, M.J.J.M. (1999). The consumption of convenience foods: reference group and eating situations. Food Quality and Preference, no. 10, pp. 457-464. 


\title{
LILIANNA JABEOŃSKA
}

INEZ WATA

Szkoła Główna Gospodarstwa Wiejskiego

Warszawa

WIOLETTA WRÓBLEWSKA

Uniwersytet Przyrodniczy

Lublin

\section{WPŁYW WYBRANYCH CZYNNIKÓW DEMOGRAFICZNO- -EKONOMICZNYCH NA POSTAWY MIESZKAŃCÓW WARSZAWY DOTYCZĄCE OWOCÓW I WARZYW SPOŻYWANYCH W FORMIE ŻYWNOŚCI WYGODNEJ}

\begin{abstract}
Abstrakt
Majac na względzie fakt, że rynek owocowo-warzywny jest istotnym segmentem sektora spożywczego, przeprowadzono badania preferencji mieszkańców Warszawy w zakresie produktów owocowych $i$ warzywnych z grupy żywności wygodnej, z uwzględnieniem znajomości i popularności tego typu produktów, ocena poglądów i postaw w stosunku do tej formy żywienia, powodów i deklarowanej częstotliwości zakupu. Wykazano, że konsumenci reprezentuja wobec żywności wygodnej raczej średni poziom zainteresowania, a zmiennymi różnicujacymi czynniki wyboru produktów owocowych $i$ warzywnych sa przede wszystkim wiek i status społeczny. Innymi determinantami wyboru były też smak, świeżość, zapach, barwa i jakość. Wzrost popularności produktów żywności wygodnej, w tym owocowych $i$ warzywnych, bedzie $w$ dużej mierze uzależniony od właściwych działań promocyjnych. Posunięcia te powinny mieć na celu nie tylko informowanie konsumentów o nowych produktach, ale kłaść nacisk przede wszystkim na wykształcenie pozytywnych przekonań do tego typu żywności oraz dostosowanie oferty do struktury potrzeb różnych grup nabywczych. Najcześsciej nabywanymi produktami będa prawdopodobnie soki i napoje, koncentraty i przeciery warzywne stanowiace komponent do przygotowywania posiłków oraz produkty mrożone, nabywane w okresie ograniczonej podaży produktów świeżych.
\end{abstract}

Słowa kluczowe: konsumpcja, żywność wygodna, produkty owocowe i warzywne.

Accepted for print: 20.06 .2017$.

Unless stated otherwise all the materials on the website are available under the Creative Commons Attribution 3.0 Poland license. Some rights reserved to the Institute of Agricultural and Food Economics - National Research Institute.

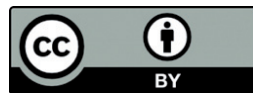

